\title{
THE DEBRIS DISTRIBUTION MODEL FOR REMOVAL PLANNING OF AN URBANIZED ESTUARINE COMPLEX
}

\author{
Walter Barrella (1) 1,2, Edineia Farraboti (10 2,3, Amanda Aparecida Carminatto (10 4,5, \\ Fabiola Andrea Chofard Adami (10 6, Matheus Marcos Rotundo (1) 2, \\ Milena Ramires (i] 2, Miguel Petrere Júnior (i) 2,5,7 \\ ${ }^{1}$ Instituto Cências da Saúde, Universidade Paulista, Sorocaba, Brazil \\ ${ }^{2}$ Programa Pós-Graduação Ecologia, Universidade Santa Cecília, Santos, Brazil \\ ${ }^{3}$ Serviço Social da Industria, Santos, Brazil \\ ${ }^{4}$ Núcleo de Tecnologia Marinha e Ambiental, São Paulo, Brazil \\ ${ }^{5}$ Programa Pós-Graduação Ecologia, Universidade Federal de São Carlos, Sorocaba, Brazil \\ ${ }^{6}$ Programa de Pós-graduação Segurança Pública, Universidade Santa Cecília, Santos, Brazil \\ ${ }^{7}$ Núcleo Ecologia e Pesca Amazônica, Universidade Federal do Pará, Belém, Brazil
}

Manuscript received: October 18, 2019

Revised version: March 2, 2021

Barrella W., Farraboti E., Aparecida Carminatto A., Chofard Adami F.A., Rotundo M.M., Ramires M., Petrere Jr M., 2021. The debris distribution model for removal planning of an urbanized estuarine complex. Quaestiones Geographicae 40(1), Bogucki Wydawnictwo Naukowe, Poznań, pp. 97-107. 4 figs, 2 tables.

\begin{abstract}
AвSTRACT: We checked the spatial pattern of debris stranding at Praia de Santos (Brazil) in the first hour after the peak of high and low tide in summer and winter. We recorded and counted 20 types of debris (natural and anthropogenic) in 6 transects arranged in 3 zones along the beach (deposition, transport, and erosion). Canonical Correspondence Analysis (CCA) showed that buoyancy was an essential property in distinguishing debris stranding behaviours. The erosion zone, closer to the estuary showed that many mollusk shells, ropes and rocks, while plastics, styrofoam and fiber nylon were in the deposition zone. Throughout the estuary, we inspected the beach, identifying sections of origin and accumulation associated with the circulation system and currents. We propose the removal and recycling of debris from accumulation sites near highways and urban systems.
\end{abstract}

KEYWORDS: beach hydrodynamics, marine waste, anthropic litter, stranded debris

Corresponding author: Walter Barrella; walterbarrella@gmail.com

\section{Introduction}

Stranded marine litter on beaches on all coasts has become a matter of worldwide concern. Studies about anthropogenic marine litter do not consider residues of natural origin, such as plant and animal remains (Defeo et al. 2009). Natural debris plays a vital role in beaches, since it stabilises the dune fronts (Nordstrom 2019) which support bird nests (Swaisgood et al. 2018) and provides housing for creatures that have few shelters to live, on open beach (Aguilera 2018, Garcia-Vazquez et al. 2018). Seaweed and leaf litter nourish the macrofauna (Gómez et al. 2018), providing the soil with rich nutrients for land plants on beaches, thereby mitigating tidal 
destruction (Rodil et al. 2019). Despite this, debris, whether natural or not, causes aesthetic problems and environmental health risks and is therefore considered improper and for this reason it is systematically removed with heavy machinery harming the beach habitat (StellingWood et al. 2016, Zielinski et al. 2019).

Cleanliness is the most important focus, but classification of information and beaching patterns could contribute to marine waste prevention and control plans. Methods that are used to estimate the amount of marine debris on beaches do not enable us to obtain information concerning waste at sea. In some coastal habitats, the litter may be of terrestrial origin, being carried by rivers, winds and municipal drainage systems, or are directly discarded on the beaches by bathers (Asensio-Montesinos et al. 2019). A smaller portion comes from fishing-related marine sources, ship disposal and storm-driven hydrodynamic changes (Asensio-Montesinos et al. 2019). There is a lack of studies that consider the interactions between natural and anthropogenic debris in the beach environment. Mir-Gual et al. (2015) showed that the Blue Flag classification does not characterise the natural systems of coastal beaches. Rather, the levels of human influence and artificiality are focused on the services offered to users, without considering beaches as fragile systems.

Beach bed ratings reflect the balance prevailing between inputs and outputs, beaching, degradation and cleanliness. Factors that influence debris density, such as cleanliness, storms, rainfall, tides and hydrological changes, can alter their count, leading to beach litter composition (Galgani et al. 2015). Factors that influence debris accumulation in coastal areas include beach morphology, location and debris (Turra et al. 2014). Experiments with drift models indicate a good correlation of water flow with litter abundance on beaches (Yoon et al. 2010, Kataoka et al. 2013, Galgani et al. 2015). Litter abundance and composition are often between different parts of a single beach (Claereboudt 2004). The mosaic distribution pattern is the most common pattern because of beach topography, especially for smaller and lighter items that are more easily dispersed (Debrot et al. 1999, Galgani et al. 2015). Glasses and hard plastics accumulate more easily on rocky shores (Moore et al. 2001), while litters concentrate on sheltered, wind-free beaches to take them to the sea, indicating regular inputs (Galgani et al. 2000, Costa et al. 2010). Patterns and beach litter accumulation cycles are revealed with records after an initial cleanup (Ryan et al. 2009). Here, we present a study of beached debris in Santos Beach, before cleaning, in the first hour after the high and low tide upholstery, in summer and winter. We evaluate the distribution, types and quantities of anthropogenic and natural (marine and terrestrial) debris stranded on the beach and provide a baseline for inferring stranded debris throughout the estuary.

\section{Study area and methods}

The Santos-São Vicente Estuarine Complex has several meandered channels which are interconnected with Santos Bay through two channels (Fig. 1). With $231 \mathrm{~km}^{2}$ of mangrove swamps, most of them are irregularly occupied, forming large densities of shacks and slums that house a population of over 150,000 people. Fresh sewage and domestic waste compromise estuary waters and pollute beaches, becoming a significant public health problem (CETESB 2017). Santos Beach extends for $5.5 \mathrm{~km}$ of a sandy strip with fine-grained sediments, homogeneous and with sub-horizontal slope (slope $<10^{\circ}$ ), which characterizes it as the dissipative type (Mclachlan, Erasmus 1983). The presence of six drainage channels interferes with the hydrodynamic regime of the beach (Fig. 1).

\section{Bathymetry and geomorphology}

The Santos Estuarine System has a complex morphological configuration, namely, multiple headwaters, extensive wetlands with mangroves and mud banks, and various connections with the adjacent ocean. Three estuaries and a bay compose the hydrographic system: the Bertioga Canal Estuary, the Porto Santos Canal Estuary and the São Vicente Estuary, the last two of which have their outlets in the Santos Bay (Roversi et al. 2016a).

At the bottom of Port of Santos Estuary, there is a thick layer of fine unconsolidated sediment (silt and clay) and a small portion of sand and depth that reaches $15 \mathrm{~m}$ due to dredging (Torres et al. 2009, Demarco 2019). The western portion 

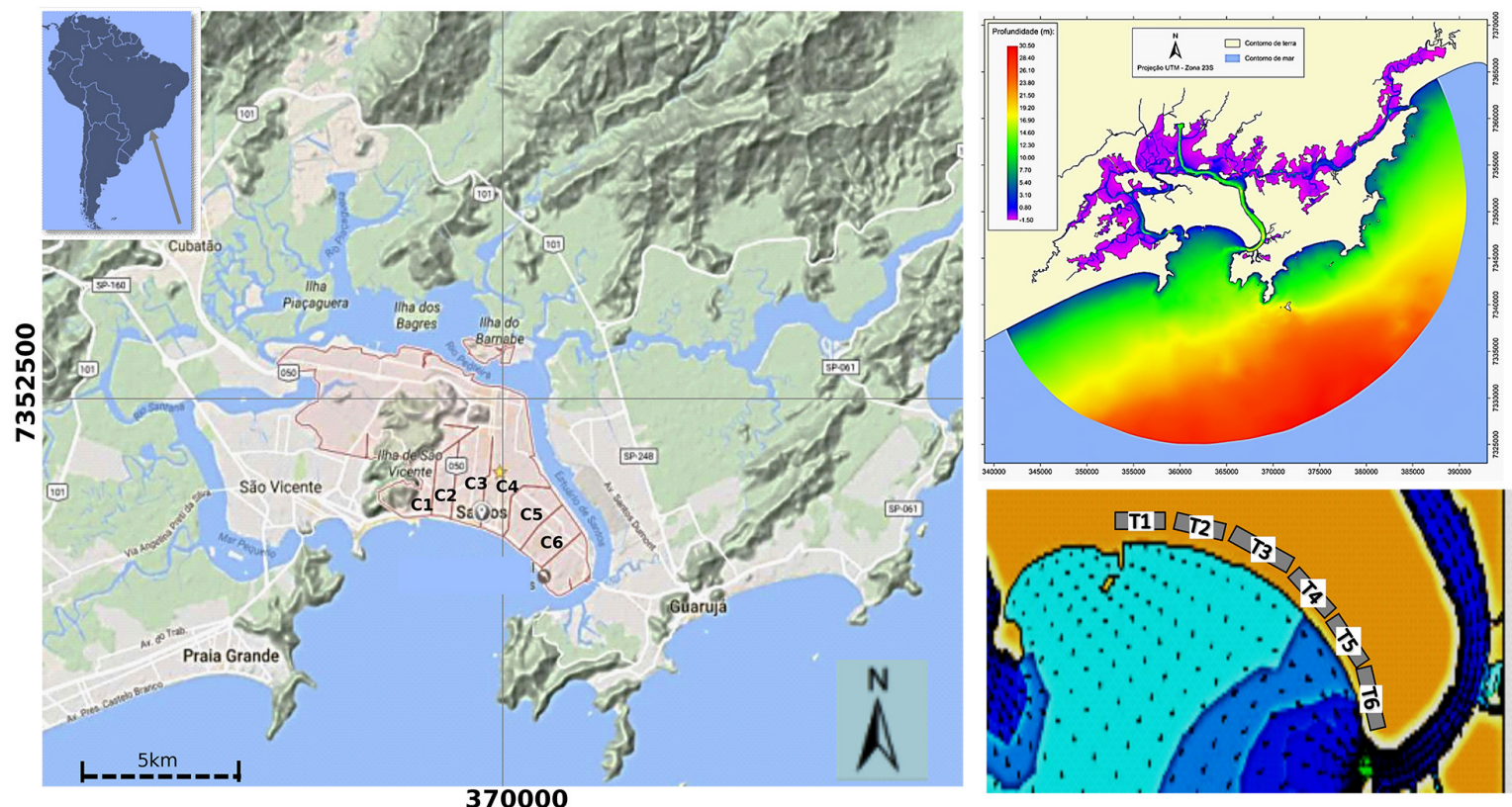

Fig. 1. Study area, with geomorphological, bathymetric, and drainage details and the location of the sample transects (T1-T6) on Santos Beach.

of Santos Bay has a sandy and muddy predominance, and in the eastern portion, there are fine sediments confined to the mouth of the Porto channel. The bay's depth can reach up to $10 \mathrm{~m}$ in depth (Harari, Camargo 1998, Rocha 2003).

\section{Climatic characteristics}

The study area's climate is characterised as humid tropical with high rainfall, since it has an average annual temperature of $19.72 \pm 3.39^{\circ} \mathrm{C}$ and an annual rainfall of $0<1735<3028 \mathrm{~mm}$ (Harari et al. 2008). The average annual rainfall in the region is $2131 \mathrm{~mm}$, with August being the driest month $(155 \mathrm{~mm})$ and February being the wettest month $(422 \mathrm{~mm})$. The rainy season, which runs from October to April, corresponds to $64 \%$ of the total annual rainfall. The dry season, which runs from April to September, presents only a few sporadic episodes of precipitation associated with the passage of cold fronts. Due to the maritime influence, rainfall throughout the year has a homogeneous distribution. In winter, although the temperature has a reduced annual amplitude $\left(17.33 \pm 3.39^{\circ} \mathrm{C}\right)$, this season is not characterised by a dry period. However, summer has high rainfall and an average temperature of $21.77 \pm 1.89^{\circ} \mathrm{C}$, which is characteristic of this region, and winter is the drought-period (Santos 1965, Pellegatti 2007, Harari et al. 2008). Winds in the area have an average speed of $0<1.49<3.77 \mathrm{~ms}^{-1}$ with a predominance of east winds in all climatic seasons (Harari et al. 2008).

\section{Hydrodynamics and water circulation}

The Santos Bay, which is oriented to the south, experiences waves generated by the south quadrant's frontal systems. Moreover, it also experiences winds coming from the tropical systems and the polar systems in relation to its latitudinal position. Due to these climatic characteristics and the absence of significant drainage basins, the rainfall regime is of great importance in transporting continental water and sediments to the ocean (Farinnaccio et al. 2009).

There is a trend of transport from east to west from the Porto channel, and there is a large deposition zone in the central-west portion, where confluence between the residual sediment transport from the São Vicente and Porto channels occurs. The east-west transport at the mouth of the Santos Bay is related to the bottom currents with the same direction since it has a predominance of sands transported by traction together at the bottom (Rocha 2003).

The tidal regime presents maximum amplitudes less than $2 \mathrm{~m}$ and semidiurnal predominance (Roversi et al. 2016a). The current patterns of summer and winter by the wind are similar, 
thereby ensuring that the tide represents the main conditioning factor of circulation within the estuarine system, with the ebbing currents predominant in the area (Harari, Camargo 1998). Currents' speed of the order is $0.25 \mathrm{~m} / \mathrm{s}$ and $0.3 \mathrm{~m} / \mathrm{s}$ in the Santos Estuary, with maximum values, observed in the channel of the Port of Santos, and the speed of the tidal currents are higher in the syzygy when compared with the values obtained in the quarter, with maximum 0.2 and $0.05 \mathrm{~m} / \mathrm{s}$, respectively (Carneiro et al. 2014). In addition to tidal variations, there is a movement resulting from the volume of freshwater constantly added by river flows generating a circulation component that naturally moves down the estuary and through the most superficial layer.

\section{Sampling and data analysis}

We sampled in the summer of 2017 and the winter of 2018. Two collections were performed at each time of the year, $1 \mathrm{~h}$ after tidal upholstery, to avoid tidal interference. We defined six transects with $6 \mathrm{~m}$ wide lanes, at the limits of seawater, two in the deposition zone (T1 and T2), two in the transport zone (T3 and T4) and two in the erosion zone (T5 and T6) from Santos Beach (Table 1).

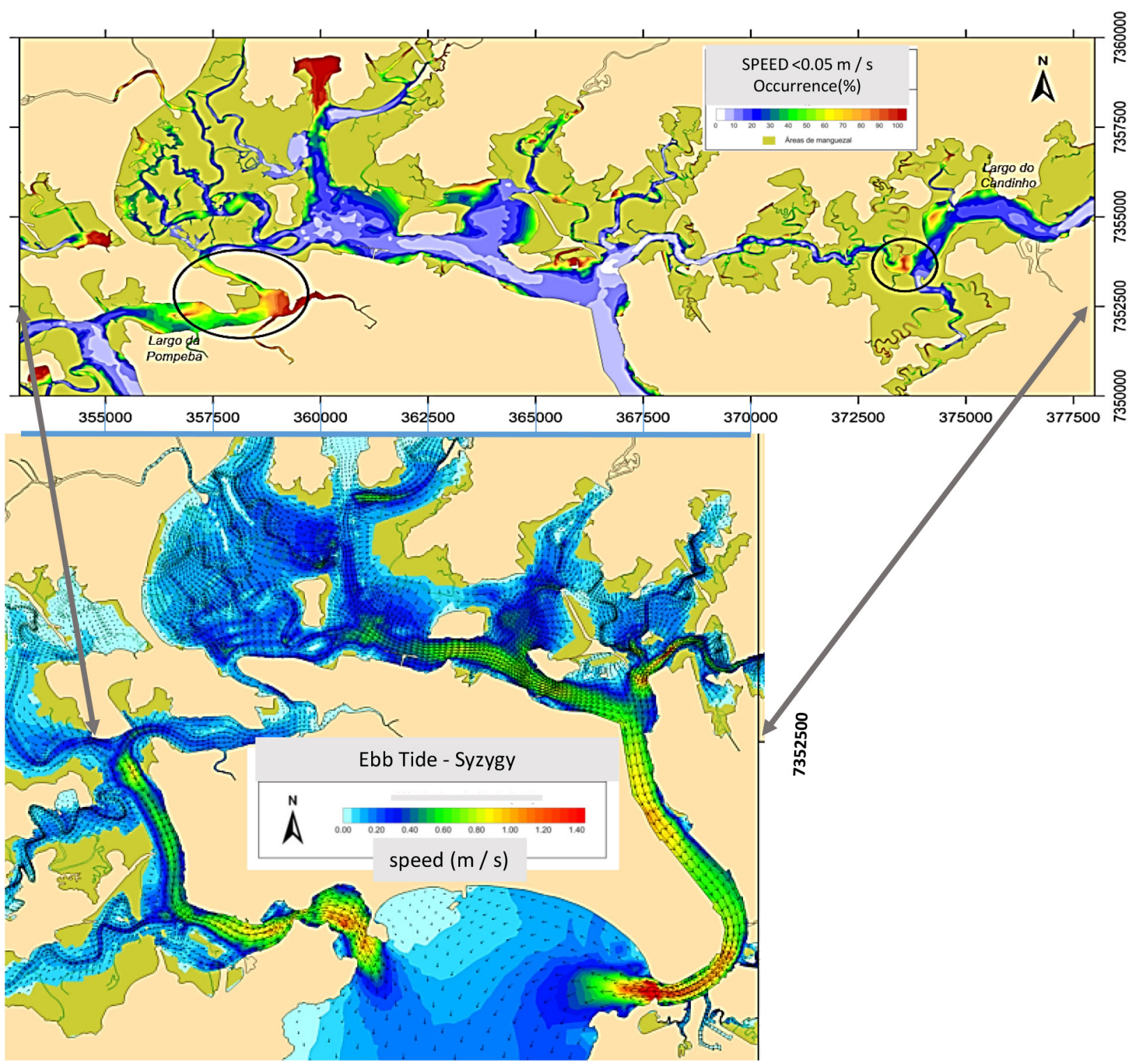

Fig. 2. Extreme hydrodynamic scenarios. Below: maximum speed, caused by the ebb tide. Above: places of occurrence of zero currents (modified from Roversi et al. 2016b). 
Table 1. Characteristics of the transects of the researched beach.

\begin{tabular}{|c|l|r|r|r|}
\hline \multirow{2}{*}{ Transect } & \multirow{2}{*}{ Zone } & Length & Width & $\begin{array}{c}\text { Distance } \\
\text { to estuary }\end{array}$ \\
\cline { 3 - 5 } & & \multicolumn{3}{|c|}{$[\mathrm{m}]$} \\
\hline T1 & Deposition & 735 & 190 & 5000 \\
\hline T2 & Deposition & 650 & 200 & 4430 \\
\hline T3 & Transport & 1050 & 225 & 3700 \\
\hline T4 & Transport & 820 & 125 & 3000 \\
\hline T5 & Erosion & 720 & 80 & 2250 \\
\hline T6 & Erosion & 1230 & 60 & 1290 \\
\hline
\end{tabular}

We categorised debris into 20 predetermined types, six natural and 14 anthropic. Among the natural residues, the following were found: a) chordata (carcasses of vertebrate animals: fish, birds, and turtle), b) Echinoderm (starfish and crackers), c) shell (shellfish and gastropod shells), d) Cnidarian, e) vegetation (leaves, branches, seedlings, seeds), and f) stones and other minerals. Among the residues of anthropic origin, the following were found: a) organic remains (fruits, vegetables and food), b) cigarette, c) strings, d) styrofoam, e) wood (machined), f) metals, g) nylon, h) paper, i) fabric, j) foam, k) glass, l) rubber, $\mathrm{m})$ hard plastic (caps, bottles, glass), and n) nonhard plastic (bags and packaging). We count all types of garbage equal to or larger than $2 \mathrm{~cm}$ in an entire beach range of $31,000 \mathrm{~m}^{2}$. We performed a canonical correspondence analysis (CCA) (Hammer et al. 2001) to relate patterns between bed characteristics and beach environment.

CCA is a multivariate method which is used to elucidate the relationships between two sets of information, in this case, debris and the conditions of the stranding environment. The method is designed to extract synthetic environmental gradients from ecological data sets. Gradients are the basis for briefly describing and visualising the differential characteristics of different debris types' stranding sites, using an ordering diagram. The CCA adds all the power of the regression methodology to the ranking. Aske linear regression CCA uses linear combinations of environmental (explanatory) variables to explain debris variables (response) optimally. The CCA's unusual characteristics are that the adjustment measure is unconventional (weighted variation of the debris' centroids) and that the data for many species are explained simultaneously. The main result is an ordering diagram, a graph with a coordinate system formed by ordering axes (that is, the synthetic gradients extracted by CCA). The coordinates of the location points are the values (called scores) of the two best synthetic gradients (axes 1 and 2). Each gradient is standardised for zero weighted average and unit weighted variance, and the debris is represented by its niche centre along each axis, that is, by the weighted average of the axis scores of the locations where they occur.

Consequently, each point of debris in the diagram is at the centroid (weighted average) of the points at the location where it occurs. The debris points, therefore, indicate their relative locations of the two-dimensional niches in the ordering diagram. The CCA also displays the environmental variables by the weights that each variable has in the linear combinations that form the axes (Ter Braak, Verdonschot 1995, Wagner 2004).

By examining the image of $06 / 11 / 2018$ on Google Earth, we verified the points of accumulation of debris along the flooded region in the study area. The altitude of the $50 \mathrm{~m}$ viewpoint allowed the identification of the predominant types of debris (floating or heavy) at each accumulation site. Accumulation points for debris near urban areas were also confirmed using Google Earth's Street View tool. We classified the accumulation points according to the predominance of debris in three categories: 1) floating (yellow markers), 2) heavy and landfills (red), and 3) potential collection and recycling point (green). The latter points showed large amounts of debris close to the road structure, where some reuse or recycling already occurs.

\section{Results}

We recorded 26,458 items across the beach, with an overall average speed of 0.21 item $\mathrm{m}^{-2} \mathrm{~h}^{-1}$. Mangrove vegetation, shells and sand dollars are predominantin the natural litter category, as are rigid plastics, non-rigid plastics and machined wood between anthropogenic debris (Table 2). CCA analysis showed a clear separation between the stranding patterns of the items concerning the Santos Beach position. The CCA1 axis separated the items with the distance from the source, that is, from the Santos Port-channel exit. In these places, the currents' erosive force, unable to displace the heaviest and low buoyancy items, were deposited in those transects which were closest to the estuary channel exit, while the lighter ones were 
distributed in more distant transects. The CCA2 axis separated the most buoyant items (Styrofoam, cnidaria, wood and rigid plastic) from those with the least buoyancy (echinoderms, paper, soft plastic, fabric, nylon and foam). Floating items were in the deposition zone, while the less buoyant items were in the beach transport zone. This analysis explains $56.1 \%$ of the total change (Fig. 3).

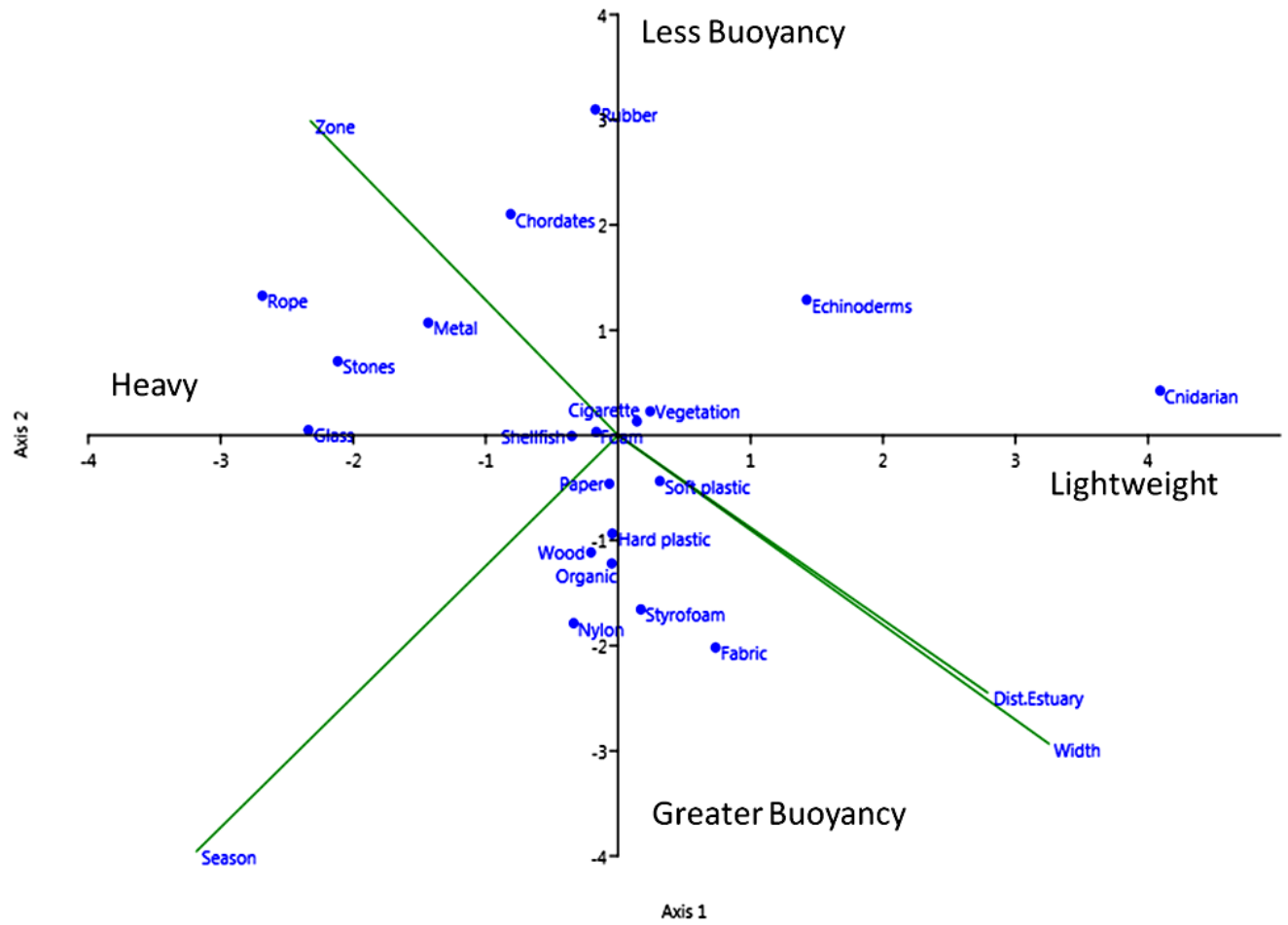

Fig. 3. Axes of the CCA for material characteristics relationships and beaching locations (season, estuary distance, width, and beach zone). CCA, canonical correspondence analysis.

Table 2. Numerical amount of debris recorded in transects.

\begin{tabular}{|c|c|c|c|c|c|c|c|}
\hline Debris & $\mathrm{T} 1$ & $\mathrm{~T} 2$ & T3 & $\mathrm{T} 4$ & T5 & T6 & Total \\
\hline Shell & 295 & 122 & 98 & 161 & 3630 & 11,786 & 16,092 \\
\hline Vegetation & 159 & 77 & 216 & 273 & 311 & 4465 & 5501 \\
\hline Rigid plastic & 526 & 271 & 101 & 147 & 175 & 440 & 1660 \\
\hline Echinoderms & 47 & 175 & 123 & 267 & 355 & 138 & 1105 \\
\hline Non-rigid plastic & 92 & 100 & 54 & 90 & 167 & 375 & 878 \\
\hline Stones & 0 & 3 & 13 & 22 & 137 & 93 & 268 \\
\hline Wood & 26 & 13 & 23 & 19 & 24 & 66 & 171 \\
\hline Cnidarian & 7 & 0 & 129 & 1 & 0 & 1 & 138 \\
\hline Chordata & 14 & 4 & 0 & 14 & 26 & 57 & 120 \\
\hline Styrofoam & 8 & 27 & 21 & 14 & 6 & 18 & 94 \\
\hline Organic & 21 & 4 & 7 & 15 & 15 & 22 & 84 \\
\hline Metal & 2 & 2 & 3 & 9 & 35 & 21 & 72 \\
\hline Cigarette & 10 & 9 & 2 & 6 & 7 & 32 & 66 \\
\hline Foam & 30 & 1 & 0 & 4 & 22 & 5 & 62 \\
\hline Glass & 3 & 2 & 1 & 3 & 13 & 21 & 43 \\
\hline Paper & 11 & 0 & 5 & 0 & 5 & 9 & 30 \\
\hline Fabric & 18 & 3 & 0 & 1 & 2 & 4 & 28 \\
\hline Nylon & 6 & 6 & 0 & 2 & 3 & 4 & 21 \\
\hline Rubber & 2 & 0 & 1 & 2 & 8 & 5 & 18 \\
\hline Rope & 0 & 0 & 0 & 1 & 3 & 3 & 7 \\
\hline Total & 1277 & 819 & 797 & 1051 & 4944 & 17,565 & 26,458 \\
\hline
\end{tabular}



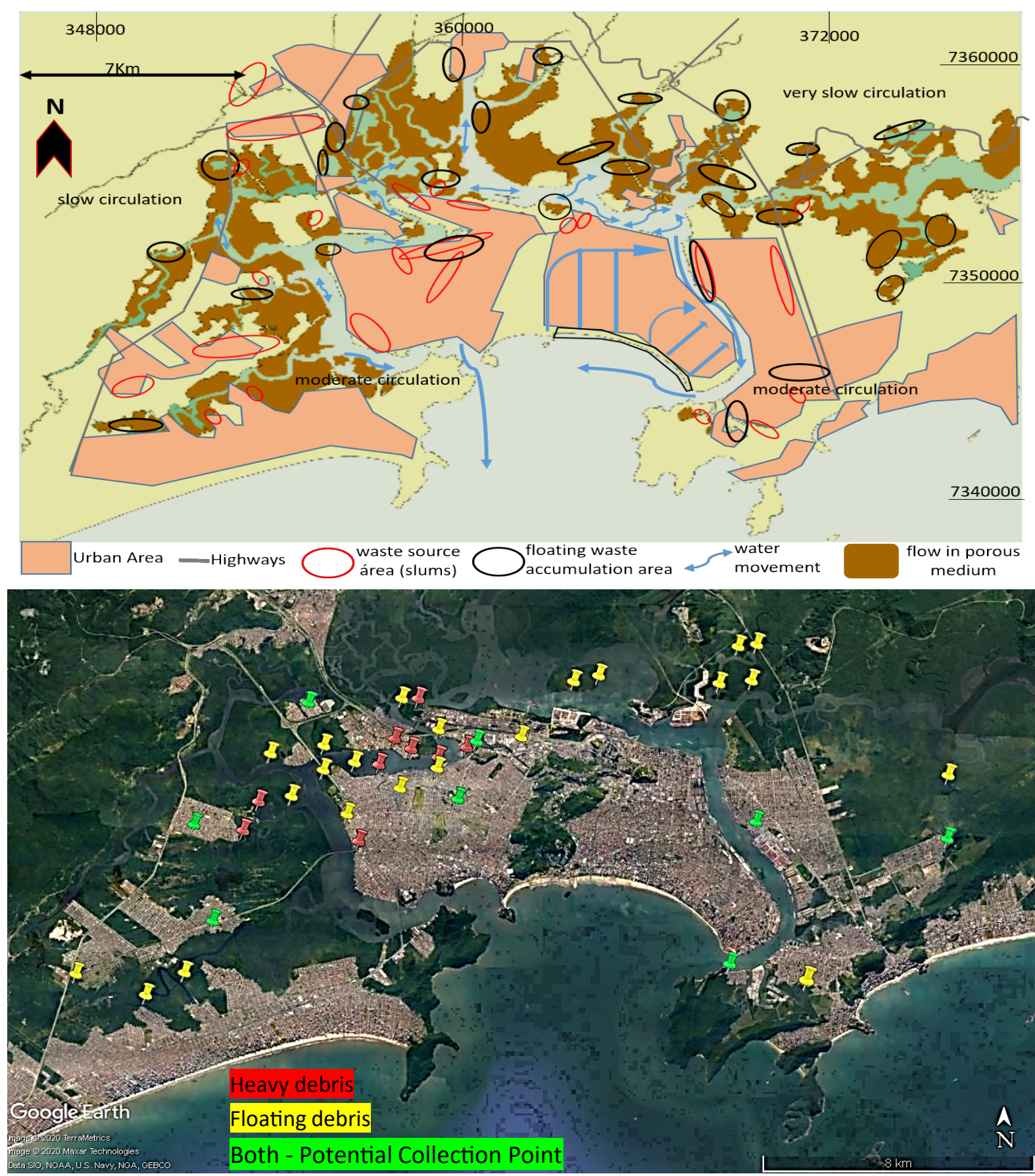

Fig. 4. Above: Water circulation and possible debris areas (based on Roversi et al. 2016b). Below: Debris accumulation points, verified by Google Earth image.

Based on the behaviour of displacement and deposition of debris on the beach, obtained in the CCA model, and based on the water circulation system (Roversi et al. 2016a), we surveyed possible points of origin and accumulation of debris inside the estuarine complex, which were confirmed through the Google Earth image (Fig. 4).

\section{Discussion and conclusion}

The beaching level of debris observed in this study $\left(0.21\right.$ item $\mathrm{m}^{-2} \mathrm{~h}^{-1}$ or 5.04 item $\left.\mathrm{m}^{-2} \mathrm{~d}^{-1}\right)$ was close to the pollution index range of Brazilian beaches (Tourinho, Fillmann 2011) and the regional coasts of South Africa (Madzena, Laisak 1997). However, this study's beach pollution 
level was considerably higher than that of many beaches in Asian countries (Thushari et al. 2017), implying the need to strengthen coastal management programs and initiate consistent control mechanisms for coastal pollution with shortand long-term actions. Our estimate, however, considers short periods after the first hour and after the tidal upholstery, without considering the influence of the spring and storm tides in the region. Therefore, the amount and distribution of beached debris on the beach vary in a way that is not fully known, and this takes place predominantly when heavy rainfall that is associated with flooding in urban areas changes the estuary's internal hydraulic flow. Storms and hangovers that produce strong tidal currents, waves and winds also bring debris from other areas to Santos beaches (Young 2016).

CCA showed that the estuary's mouth was the stretch where the highest concentration of heavy and less buoyant debris occurred, such as mollusk shells, ropes, glass, stones and metals. Lighter debris was transported to farther stretches of the estuary by lateral drift (Cordeiro et al. 2018). Those with the highest buoyancy (plastics, Styrofoam and wood) were distributed along the beach, while less floating material debris (foam, paper, fabric and nylon) concentrated in the deposition zone, where there is low ocean-circulation due to the construction of the emissary near Urubuqueçaba Island. The T3 transect was recorded as an entry of marine planktonic organisms (cnidarian) that originate from the open sea and are transported by surface currents to the beach (Alfredini et al. 2008, Pion, Bernardino 2018).

Relating to the presence of marine litter with hydrodynamic characteristics of the beach-estuary system, we can understand the distribution of different items and evaluate the surveyed litter (Ioakeimidis et al. 2017). Shells and other more massive debris exhibited stranding behaviours which were at variance with lighter, floating debris. Similar to studies by Rocha (2003) and Magini et al. (2007) using particle size parameters, residual sediment transport in Santos Bay was measured, and a transport tendency from the estuary channel towards the open sea was verified to be passing towards the western portion of the bay. Therefore, we postulate that the most likely origins are those located near the entrance of the Santos channel, where the moderate flow was the main factor for stranding debris within the sample time $(1 \mathrm{~h})$, including some slums (vulnerable cores) and the drained waters of the city's urban area. We can assume that the heavy debris came from sources near the port estuary canal, where circulation is moderate. In the inside areas of the estuary, heavy debris accumulates continuously and is even used in clandestine landfills to expand disorderly human occupation. This material obstructs channels and impairs water circulation and consequently also impairs the quality of estuarine waters. Contaminant release, decomposition of organic matter and increased concentration of coliforms also contaminate sediment and fishery resources (Buruaem et al. 2013, Campuzano et al. 2013, Gillam, Charles 2019, Val et al. 2019). The heavy debris is deposited on the bottom, close to its area of origin (slums), with slow displacement and influenced by the strong currents produced during rains and extreme tides.

Besides, heavy debris is used to land mangrove areas to ensure that new areas can be occupied illegally (Zündt 2006). This landfill modifies water circulation and changes the vegetation that progressively becomes an urban periphery area, with a greater population concentration in vulnerable conditions (Gulis et al. 2004). More than 120,000 people live in 74 vulnerability centres located within the area of estuarine influence. With an average growth of $6 \%$ per year, there is a strong tendency to increase the occupied area, causing an increased hydraulic and sanitary impact on the estuary's internal area (Gillam, Charles 2018, 2019, Moschetto et al. 2020, Ferreira, Lacerda 2016).

Floating waste accumulation occurs in areas that have a slow circulation system. The extensive internal mangrove area acts as a filter (porous flow) that accumulates floating debris, the release of which depends on stochastic situations of flows, currents and rainfall (Horton et al. 2017, Zhang 2017). Based on the region's estuarine circulation models (Fernandino et al. 2016, Roversi et al. 2016b), we identified sites with low current velocities, which would allow the accumulation of floating debris. Knowledge of these areas may be of great interest in the strategic development of litter removal before it enters the sea or spreads on the beach (Iñiguez et al. 2016). Selective waste 
collection and recycling plants could be installed near vulnerable nuclei, reducing inappropriate disposal and providing employment and income for residents (Perivier et al. 2016).

On the other hand, there is floating garbage, which moves quickly and typically accumulates in internal areas with weak currents. However, in extreme rain and tides, the floating garbage is carried by the currents, and is thrown by the channel to Santos Beach. Thereafter, the coastal drift current (east-west) distributes the debris over the beach's entire length. The speed gradient is responsible for separating the less floating garbage, which is concentrated in the beach's central portion, from those with greater buoyancy found in the western portion of the beach (Transects 1 and 2). Cordeiro and Costa (2010) evaluated the ecological characteristics and solid wastes accumulated along with the Santos - Sao Vicente Estuary Complex. They verified the dominance of floating garbage (plastic and wood), accumulated in the highest areas with the low influence of the medium heights of the high tide, where there are few young plants of mangrove vegetation which reflect the influence of the slope on the deposition of items.

The locations identified (Fig. 4) with both (heavy and floating) present conditions for installations for the debris collection and recycling system. Some of them have infrastructure facilities in the proximity of the main highways and areas already used for sorting materials. Thus, given the strong trend of disorderly occupation, with rapid human growth and accumulation of debris, the proposal to install recycling plants could contribute to regional development planning and minimised debris impact and facilitate the innovative development of alternative ways of generating income for the local poor.

\section{Author's contributions}

WB: coordination; EF: coordination of fieldwork; AAC: fieldwork, writing; FACA: fieldwork; MMR: fieldwork; MR: fieldwork; MPJ: analysis.

\section{Funding}

This study was financed in part by the Coordenação de Aperfeiçoamento de Pessoal de Nível Superior - Brazil (CAPES) - Finance Code 001.

\section{Acknowledgments}

We thank the Graduate Program in Ecology at Santa Cecília University - UNISANTA - for supporting this research. And to the reviewers of the article, whose criticisms and suggestions contributed to this publication's success.

\section{References}

Aguilera M.A., 2018. Artificial defenses in coastal marine ecosystems in Chile: Opportunities for spatial planning to mitigate habitat loss and alteration of the marine community structure. Ecological Engineering 120: 601-610. DOI 10.1016/j.ecoleng.2017.04.021.

Alfredini P., Arasaki E., do Amaral R.F., 2008. Mean sea-level rise impacts on Santos Bay, Southeastern Brazil - A physical modeling study. Environmental Monitoring and Assessment 144(1-3): 377-387. DOI 10.1007/s10661-007-0001-z.

Asensio-Montesinos F., Anfuso G., Williams A.T., 2019. Beach litter distribution along the western Mediterranean coast of Spain. Marine Pollution Bulletin 141: 119-126. DOI 10.1016/j.marpolbul.2019.02.031.

Buruaem L.M., de Castro Í.B., Hortellani M.A., Taniguchi S., Fillmann G., Sasaki S.T., Bíceg M.C., Maranho L.A., Davanso M.B., Nonato E.F., Cesar A., Costa-Lotufo L.V., de Souza Abessa D.M., 2013. Integrated quality assessment of sediments from harbour areas in Santos-São Vicente Estuarine System, Southern Brazil. Estuarine, Coastal and Shelf Science 130: 179-189. DOI 10.1016/j.ecss.2013.06.006.

Campuzano F.J., Mateus M.D., Leitão P.C., Leitão P.C., Marín V.H., Delgado L.E., Tironi A., Pierini J.O, Sampaio A.F.P., Almeida P., Neves, R.J., 2013. Integrated coastal zone management in South America: A look at three contrasting systems. Ocean \& Coastal Management 72: 22-35. DOI 10.1016/j.ocecoaman.2011.08.002.

Carneiro J., Molinas E., Nemes D., Gallo M., Vinzón S., Araújo A., 2014. Hydrodynamic modeling and residual velocities in Santos Estuarine Complex (SP, Brazil). In: Proceedings of the 17th Physics of Estuaries and Coastal Seas (PECS), Porto de Galinhas, Pernambuco, Brazil.

CETESB, 2017. Relatório de Qualidade das praias litorâneas do estado de São Paulo. Online: http:/ / cetesb.sp.gov.br (accessed 24 June 2019).

Claereboudt M.R., 2004. Shore litter along sandy beaches of the Gulf of Oman. Marine Pollution Bulletin 49(9-10): 770-777. DOI 10.1016/j.marpolbul.2004.06.004.

Cordeiro C.A.M.M., Costa T.M., 2010. Evaluation of solid residues removed from a mangrove swamp in the São Vicente Estuary, SP, Brazil. Marine Pollution Bulletin 60(10): 1762-1767. DOI 10.1016/j.marpolbul.2010.06.010.

Cordeiro T.C., Barrella W., Butturi-Gomes D., Petrere Júnior M., 2018. A modeling approach for reposition dynamics of litter composition in coastal areas of the city of Santos, Sao Paulo, Brazil. Marine Pollution Bulletin 128: 333-339. DOI 10.1016/j.marpolbul.2018.01.054.

Costa M., Ivar do Sul J., Silva-Cavalcanti J., Araújo M., Spengler Â., Tourinho P., 2010. On the importance of the size of plastic fragments and pellets on the strandline: A snapshot of a Brazilian beach. Environmental Monitoring and Assessment 168: 299-304. DOI 10.1007/s10661-009$1113-4$. 
Debrot A.O., Tiel A.B., Bradshaw J.E., 1999. Beach debris in Curacao. Marine Pollution Bulletin 38(9): 795-801. DOI 10.1016/S0025-326X(99)00043-0.

Defeo O., McLachlan A., Schoeman D.S., Schlacher T.A., Dugan J., Jones A., Lastra M., Scapini F., 2009. Threats to sandy beach ecosystems: A review. Estuarine, Coastal and Shelf Science 81(1): 1-12. DOI 10.1016/j.ecss.2008.09.022.

Demarco L.F.W., 2019. Caracterização dos processos sedimentares em trecho do canal de acesso ao Porto de Santos, por meio de métodos acústicos. 2019.103p. Dissertação (Mestrado em Ciências)- Instituto Oceanográfico, Universidade de São Paulo.

Farinnaccio A., Cazolli-Goya S., Tessler M.G., 2009. Variações da linha de costa nas baías de Santos e São Vicente. Quaternary and Environmental Geosciences 1(1): 2009. DOI 10.5380/abequa.v1i1.14389.

Fernandino G., Elliff C.I., Frutuoso G.A., da Silva E.V.N.M., Gama, G.S., de Oliveira Sousa, J.H., Silva, I.R., 2016. Considerations on the effects of tidal regimes in the movement of floating litter in an estuarine environment: Case study of the estuarine system of Santos-São Vicente, Brazil. Marine Pollution Bulletin 110(1): 591-595. DOI 10.1016/j.marpolbul.2016.05.080.

Ferreira A.C., Lacerda L.D., 2016. Degradation and conservation of Brazilian mangroves, status, and perspectives. Ocean \& Coastal Management 125: 38-46. DOI 10.1016/j. ocecoaman.2016.03.011.

Galgani F., Hanke G., Maes T., 2015. Global distribution, composition, and abundance of marine litter. In: Bergmann M., Gutow L., Klages M. (eds.). Marine anthropogenic litter. Springer, Berlin: 29-56.

Galgani F., Leaute J.P., Moguedet P., Souplet A., Verin Y., Carpentier A., Goraguere H., Latrouite D., Andral B., Cadiou Y., Maheg J.C., Poulard J.C., Nerisson P., 2000. Litter on the sea floor along European coasts. Marine Pollution Bulletin 40(6): 516-527. DOI 10.1016/S0025-326X(99)00234-9.

Garcia-Vazquez E., Cani A., Diem A., Ferreira C., Geldhof R., Marquez L., Molloy E., Perché, S. 2018. Leave no traces-Beached marine litter shelters both invasive and native species. Marine Pollution Bulletin 131: 314-322. DOI 10.1016/j.marpolbul.2018.04.037.

Gillam C., Charles A., 2018. Fishers in a Brazilian Shantytown: Relational wellbeing supports recovery from environmental disaster. Marine Policy 89: 77-84. DOI 10.1016/j.marpol.2017.12.008.

Gillam C., Charles A., 2019. Community wellbeing: The impacts of inequality, racism, and environment on a Brazilian coastal slum. World Development Perspectives 13: 18-24. DOI 10.1016/j.wdp.2019.02.006.

Gómez M., Barreiro F., López J., Lastra M., 2018. Effect of upper beach macrofauna on nutrient cycling of sandy beaches: Metabolic rates during wrack decay. Marine Biology 165(8): 133. DOI 10.1007/s00227-018-3392-1.

Gulis G., Mulumba J.A.A., Juma O., Kakosova, B., 2004. Health status of people of slums in Nairobi, Kenya. Environmental Research 96(2): 219-227. DOI 10.1016/j.envres.2004.01.016.

Hammer O., Harper D.A.T., Ryan P.D., 2001. PAST: Palaeontological Statistics software package for education, Ver. 3.14. Online: https://folk.uio.no/ohammer/past/ (accessed 25 June 2019).

Harari J., De Camargo R., 1998. Modelagem numérica da região costeias de Santos (SP): Circulação de maré. Revista Brasileira de Oceanografia 46(2): 135-156. DOI 10.1590/ S1413-77391998000200004.
Harari L., França C.A.S., Camargo R., 2008. Climatology and hydrography os Santos Estuary. In: NEVES, Ramiro, (ed). Perspectives on integrated coastal zone management in South America. IST press, Lisboa: 147-160.

Horton A.A., Walton A., Spurgeon D.J., Lahive E., Svendsen C., 2017. Microplastics in freshwater and terrestrial environments: Evaluating the current understanding to identify the knowledge gaps and future research priorities. Science of the Total Environment 586: 127-141. DOI 10.1016/j.scitotenv.2017.01.190.

Iñiguez M.E., Conesa J.A., Fullana A., 2016. Marine debris occurrence and treatment: A review. Renewable and Sustainable Energy Reviews 64: 394-402. DOI 10.1016/j. rser.2016.06.031.

Ioakeimidis C., Galgani F., Papatheodorou G., 2017. Occurrence of marine litter in the marine environment: A world panorama of floating and seafloor plastics. Hazardous Chemicals Associated with Plastics in the Marine Environment 93-120. DOI 10.1007/698_2017_22.

Kataoka T., Hinata H., Kato S., 2013. Analysis of a beach as a time-invariant linear input/output system of marine litter. Marine Pollution Bulletin 77(1-2): 266-273. DOI 10.1016/j.marpolbul.2013.09.049.

Madzena A., Laisak, T., 1997. Spatial and temporal variations in beach litter on the Transkei coast of South Africa. Marine Pollution Bulletin 34: 900-907. DOI 10.1016/S0025326X(97)00052-0.

Magini C., Harari J., Abessa D.M.D.S., 2007. Circulação recente de sedimentos costeiros nas praias de Santos durante eventos de tempestades: dados para a gestão de impactos físicos costeiros. Geociências: 349-355.

Mclachlan A., Erasmus, T., 1983. Sandy beaches as ecosystems. Dr. W. Junk Publishers, Amsterdam.

Mir-Gual M., Pons G.X., Martín-Prieto J.A., RodríguezPerea A., 2015. A critical view of the Blue Flag beaches in Spain using environmental variables. Ocean $\mathcal{E}$ Coastal Management 105: 106-115. DOI 10.1016/j.ocecoaman.2015.01.003.

Moore C.J., Moore S.L., Leecaster M.K., Weisberg, S.B., 2001. A comparison of plastic and plankton in the North Pacific Central Gyre. Marine Pollution Bulletin 42, 1297e1300. DOI 10.1016/S0025-326X(01)00114-X.

Moschetto F.A. Ribeiro, R.B., De Freitas, D.M., 2020. Urban expansion, regeneration, and socio-environmental vulnerability in a mangrove ecosystem at the southeast coast of São Paulo, Brazil. Ocean \& Coastal Management 105418. DOI 10.1016/j.ocecoaman.2020.105418.

Nordstrom K.F., 2019. Coastal dunes with resistant cores. Journal of Coastal Conservation 23(1): 227-237. DOI 10.1007/s11852-018-0653-6.

Pellegatti C.H.G., 2007. Avaliação espaço-temporal da precipitação no perfil da Baixada Santista-Vertentes Oceânicas-Rebordo Interiorano da escarpa da Serra do Mar-SP. 2007. 128p. Dissertação (Mestrado em Geografia Física) - Universidade de São Paulo, Brazil.

Perivier H., Arrasate M.I., Georgoulias A., Killmer A., Ramirez M.C., Watkins G.G., Meller H., 2016. Serra do Mar and Atlantic forest mosaics system: Socio-environmental recovery program, Brazil. Inter-American Development Bank. Environment, Rural Development and Risk Management Division. IX. Series. Inter-American Development Bank, Washington, DC.

Pion L.M., Bernardino J.C.M., 2018. Dredging volumes prediction for the access channel of santos port considering different design depths. TransNav: International Journal on 
Marine Navigation and Safety of Sea Transportation, 12. DOI 10.12716/1001.12.03.09.

Rocha A.C., 2003. Aplicação de métodos diretos e indiretos na análise de sedimentos na Baía de Santos- SP. 2003. 70p. Dissertação (Mestrado em Oceanografia) - Instituto Oceanográfico, Universidade de São Paulo, Brazil.

Rodil I.F., Lastra M., López J., Mucha A.P., Fernandes J.P., Fernandes S.V., Olabarria C., 2019. Sandy beaches as biogeochemical hotspots: The metabolic role of macroalgal wrack on low-productive shores. Ecosystems 22(1): 49-63. DOI 10.1007/s10021-018-0253-1.

Roversi F., Rosman P.C.C., Harari J., 2016a. Análise das trajetórias das águas continentais afluentes ao sistema estuarino de Santos. Revista Brasileira de Recursos Hídricos 21(1): 242-250. DOI 10.21168/rbrh.v21n1.p242-250.

Roversi F., Rosman P.C.C., Harari, J., 2016b. Análise da renovação das águas do Sistema Estuarino de Santos usando modelagem computacional. Revista Ambiente \& Água 11(3): 566-585. DOI 10.4136/ambi-agua.1770.

Ryan P.G., Moore C.J., van Franeker J.A., Moloney C.L., 2009. Monitoring the abundance of plastic debris in the marine environment. Philosophical Transactions of the Royal Society B: Biological Sciences 364(1526): 1999-2012. DOI 10.1098/ rstb.2008.0207.

Santos E.O.A., 1965. Baixada Santista: Aspectos geográficos. Editora da Universidade de São Paulo, São Paulo, 1(4): 95-150.

Stelling-Wood T.P., Clark G.F., Poore A.G., 2016. Responses of ghost crabs to habitat modification of urban sandy beaches. Marine Environmental Research 116: 32-40. DOI 10.1016/j.marenvres.2016.02.009.

Swaisgood R.R., Nordstrom L.A., Schuetz J.G., Boylan J.T., Fournier J.J., Shemai B., 2018. A management experiment evaluating nest-site selection by beach-nesting birds. The Journal of Wildlife Management 82(1): 192-201. DOI 10.1002/jwmg.21342.

Ter Braak C.J., Verdonschot P.F., 1995. Canonical correspondence analysis and related multivariate methods in aquatic ecology. Aquatic Sciences 57(3): 255-289. DOI 10.1007/BF00877430.

Thushari G.G.N., Chavanich S., Yakupitiyage A., 2017. Coastal debris analysis in beaches of Chonburi Province, Eastern Thailand as implications for coastal conservation. Marine Pollution Bulletin 116(1-2): 121-129. DOI 10.1016/j.marpolbul.2016.12.056.
Torres R.J., Abessa D.M., Santos F.C., Maranho L.A., Davanso M.B., Do Nascimento M.R., Mozeto A.A., 2009. Effects of dredging operations on sediment quality: Contaminant mobilization in dredged sediments from the Port of Santos, SP, Brazil. Journal of soils and sediments 9(5): 420-432. DOI 10.1007/s11368-009-0121-x.

Tourinho P.S., Fillmann G., 2011. Temporal trend of litter contamination at Cassino beach, Southern Brazil. Journal of Integrated Coastal Zone Management 11(1): 97-102. Online: http:/ / repositorio.furg.br/handle/1/2143.

Turra A., Manzano A.B., Dias R.J.S., Mahiques M.M., Barbosa L., Balthazar-Silva D., Moreira, F.T., 2014. Three-dimensional distribution of plastic pellets in sandy beaches: Shifting paradigms. Scientific Reports 4: 4435. DOI 10.1038/srep04435.

Val A.L., Bicudo C.E.D.M., Bicudo D.D.C., Pujoni D.G.F., Rosado F., Spilki F.R. Nogueira I.S., Hespanhol I., Cirilo J.A., Tundisi J.G., Val P., Hirata P., Azevedo S.M.F.O., Crestana S., Ciminelli S.T.V., 2019. Water Quality In Brazil. In: Water Quality in the Americas: 103.

Wagner H.H., 2004. Direct multi-scale ordination with canonical correspondence analysis. Ecology 85(2), 342-351. DOI 10.1890/02-0738.

Yoon J.H., Kawano S., Igawa S., 2010. Modeling of marine litter drift and beaching in the Japan Sea. Marine Pollution Bulletin 60(3): 448-463.DOI 10.1016/j.marpolbul.2009.09.033.

Young A.F., 2016. Adaptation actions for integrated climate risk management into urban planning: A new framework from urban typologies to build resilience capacity in Santos (SP). City, Territory and Architecture 3(1): 12. DOI 10.1186/s40410-016-0042-0.

Zhang H. 2017. Transport of microplastics in coastal seas. Estuarine, Coastal and Shelf Science 199: 74-86. DOI 10.1016/j. ecss.2017.09.032.

Zielinski S., Botero C.M., Yanes A. 2019. To clean or not to clean? A critical review of beach cleaning methods and impacts. Marine Pollution Bulletin 139: 390-401. DOI 10.1016/j.marpolbul.2018.12.027

Zündt C., 2006. Baixada Santista: uso, expansão e ocupação do solo, estruturação de rede urbana regional e metropolização. Novas metrópoles paulistas: população, vulnerabilidade e segregação. Campinas: Núcleo de Estudos de População/Unicamp. 